Aliran Eksistensialisme dalam Pandangan Filsafat Pendidikan Islam

Rabiatul Adawiah

Madrasah dan Transformasi Intelektual Muhdi

Kisah Keluarga Teladan dalam Al-Qur'an (Inspirasi Membangun Negara yang Thayyibah) Rahmat Sholihin

Tasawuf dalam Pandangan Nurcholish Madjid Ilham Masykuri Hamdie dalam Buku The Tao of Islam) Erni Susilawati

Islam, Keindonesiaan, dan Kemanusiaan

(Telaah Pemikiran Ahmad Syafii Maarif) Damanhuri

Pandangan Kritis Islam Liberal atas Isu-Isu Kontemporer Muhammad Taufik 


\section{AL - BANJARI \\ Jurnal Ilmiah Ilmu-Ilmu Keislaman}

Vol. 14, No. 1, Januari-Juni 2015

\section{DAFTAR ISI}

Aliran Eksistensialisme dalam Pandangan Filsafat Pendidikan Islam

Rabiatul Adawiah

Madrasah dan Transformasi Intelektual

Muhdi

Kisah Keluarga Teladan dalam Al-Qur'an (Inspirasi Membangun

Negara yang Thoyyibah)

Rahmat Sholihin

Tasawuf dalam Pandangan Nurcholish Madjid

Ilham Masykuri Hamdie

Psikologi Sufistik (Studi atas Pemikiran Sachiko Murata dalam Buku

The Tao of Islam)

60-75

Erni Susilawati

Islam, Keindonesiaan, dan Kemanusiaan (Telaah Pemikiran

Ahmad Syafii Maarif)

$76-84$

Damanhuri

Pandangan Kritis Islam Liberal atas Isu-Isu Kontemporer

85-105

Muhammad Taufik 


\title{
ISLAM, KEINDONESIAAN, DAN KEMANUSIAAN (TELAAH PEMIKIRAN AHMAD SYAFII MAARIF)
}

\author{
Damanhuri \\ Dosen INSTIKA Guluk-Guluk Sumenep Jawa Timur \\ E-mail: dmanhuri@gmail.com
}

\begin{abstract}
This paper explores the ideas of Islam, Indonesian-ness and humanity in the context of a neo-modernist thinker of Islam Indonesia, Ahmad Syafii. His thoughts on Islam are the results of his understandings of the role of ethics of the Koran in shaping attitudes and behavior of Muslims. Therefore, the impressions of peaceful and dynamic value become values that should be grounded in humanity and Indonesian-ness.
\end{abstract}

Keywords: Islam, Indonesian-ness, Humanity, and Neo-Modernist.

\section{Pendahuluan}

Musdah Mulia suatu ketika mengatakan bahwa, Ahmad Syafii Maarif merupakan "salah satu tokoh muslim Indonesia terkemuka abad ini". Ungkapan ini memiliki dasar yang kuat bahwa -walaupun tokoh kita ini dianggap sebagai "pendatang terlambat" (the late comer) oleh Clara Joewono dan Luthfi Assyaukanie, hingga menjadi salah satu alasan mengapa Greg Barton ${ }^{1}$ tidak mengulasnya dalam bukunya sebagai tokoh muslim neo-modernis- keterlibatannya baik dalam dunia akademis ataupun dalam gerakan sosial-keagamaan memiliki kontribusi yang signifikan.

Bukti sahih ini nampakpada beberapa karyanya yang telah terpublikasikan dari jeda waktu tahun 1980-an hingga sekarang.Ataupun juga keterlibatannya dalam organisasi keagamaan seperti Muhammadiyah, dan yang mutakhir adalah kontribusinya dalam mendirikan MAARIF Institute sebuah lembaga dakwah, pemberdayaan dan pencerahan.

Prestasi akademik dan non-akademik itu telah menjadikan Buya Syafii, demikian ia akrap dipanggil, sebagai Guru Bangsa yang memiliki kontribusi besar pada pencitraan Islam Indonesia. Isu-isu penting yang berkaitan dengan Islam dicetuskan dengan bahasa yang lugas, kritis dan tentu dalam bahasa yang indah dan puitis. Wawasannya sangat luas, hal ini nampak pada concern pemikirannya mulai soal nasional hingga global, seperti; sejarah, agama, kebudayaan, pemikiran, politik, dan dunia Muslim.TemaDjohan Effendi, Ahmad Wabib dan Abdurrahman Wabid (Jakarta: Paramadina, 1999) 
tema tersebut mengindikasikan bahwa si 'anak panah' Muhammadiyah ini memiliki kepekaan yang tinggi pada lingkungan sosialnya.Dengan berbekal sebagai empu dalam bidang sejarah, maka modalitas ini mengantarkannya menjadi sosok intelektual yang tulus dan berani mengungkap fakta-fakta sejarah yang mengingkari nilai-nilai kemanusiaan meskipun terkadang harus berhadapan dengan tembok opini mainstream yang terlanjur membatu.

Tulisan ini, tentu tidak akan mengulas semua persoalan yang dipotret oleh Ahmad Syafii Maarif secara keseluruhan, tapi akan mencoba mengkaji kerangka berpikirnya dalam konteks Islam sekaligus akan menelaah pemahamannya tentang Islam, Indonesia dan Kemanusiaan yang terlibat di dalamnya.

\section{"Biografi Hidup" Ahmad Syafii Maarif}

Ahmad Syafii Maarif menceritakan suasana kelahirannya dalam bahasa tutur yang apik seperti terlukis di bawah ini:

"Aku dilabirkan pada hari Sabtu, 31 Mei 1935, di sebuah rumah bertanduk empat khas Minang, buatan ayabku, di kawasan jorong kecil dan sepi bernama Calau dalam kenagarian Sumpur Kudus, Sumatera Barat. Dinding dan lantai rumah itu terbikin dari kayu dan seng sebagai atapnya. Jika aku tak salab ingat, ada bagianbagian rumah itu yang dipercantik dengan cat biru muda. Terdapat juga ukiran kayu warna-warni di sisi bagian atasnya.

Di bawah lantainya yang membujur dari utara ke selatan terdapat ruang kosong yang biasa dipakai untuk. kandang ayam dan menyimpan perkayuan yang belum terpakai. Lokasinya jika kita bergerak dari selatan ke utara berada di sebelab kiri hanya beberapa meter dari jalan umum, berupa jalan kampung, yang selama ratusan tabun sampat saat itu dan beberapa tahun setelah itu belum pernah dilintasi kendaraan bermesin..."

Sumpur Kudus adalah kawah pertama yang telah membentuk mental Buya Syafii, begitu beliau biasa dipanggil, menjadi sosok yang sederhana dan religius, karenadesa ini, seperti disebut oleh Dobbindan dipertegas oleh Buya Syafii, pada saat itu merupakan pusat bisnis perdagangan emas sekaligus juga pusat kajian Islam. ${ }^{3}$ Setelah melewati masa kecilnya di desa yang bersahaja itu, Buya Syafii melanglang buana.Pendidikan S1-nya dihabiskan di Fakultas Hukum Universitas Cokroaminoto, Solo, hingga memperoleh gelar sarjana muda. Setamat dari Fakultas Hukum, ia melanjutkan pendidikannya ke IKIP Yogyakarta, dan memperoleh gelar sarjana sejarah. Dalam upaya menekuni ilmu sejarahnya, Buya Syafii mengikuti Program Master di Departemen Sejarah Universitas Ohio, AS. Sementara gelar doktornya diperoleh dari Program Studi Bahasa dan Peradaban Timur Dekat,Universitas Chicago, AS, dengan

2 Ahmad Syafii Maarif, Titik-Titik Kisar di Perjalananku Autobiografi Abmad Syafii Maarif (Bandung: Mizan, 2009), hlm. 21.

3 Informasi mengenai kondisi kampung Sumpur Kudus ini diperoleh Buya Syafii dari penelitian yang dilakukan oleh Christine Dobbin dalam bukunya Islamic Revivalism in a Changing Peasant Economy: Central Sumatera, 1784-1847 (London \& Malmo: Curzon Press, 1983), hlm. 61-63. 
disertasi: Islam as the Basis of State: A Study of the Islamic Political Ideas as Reflected in the Constituent Assembly Debates in Indonesia.

Dari sekian perjalanan intelektual-akademis yang dilakukan, Chicago merupakan pengalaman yang luar biasa memberikan pengaruh pada pembentukan struktur berpikir Buya Syafii, tentu setelah ia bertemu dengan Fazlur Rahman. ${ }^{4}$ Dalam bahasa narasinya yang khas, beliau mengatakannya sebagai berikut:

"Saya belajar Islam sudah mulai semenjak di Ibtidaiyah Mubammadiyah, tetapi menjadi sangat mantap setelah berguru pada Prof. Fazlur Rahman selama empat tabun di Chicago. Rahman mengenalkan kepada saya pesan universalisme al-Quran melalui beberapa mata kuliah yang saya ikuti, termasuk tafsir al-Quran yang diberikannya. Saya menjadi sangat kritis terbadap berbagai pemikiran Islam, baik yang klasik maupun yang modern, setelah belajar al-Quran pada Rahman. Oleb sebab itu ada baiknya bila seorang ingin mengenal pemikiran saya, mohon dibaca juga karya-karya Rabman, sekalipun saya tidak. mungkin menyamai otoritas keilmuannya dalam soalsoal keislaman."

Menyebut nama Fazlur Rahman, tokoh ini tidak hanya memberi warna pada diri Buya Syafii tapi juga telah mewarnai sekian tokoh penting di Indonesia pada dekade abad 20-an dengan gerakan neo-modernisme Islam, sebut saja misalnya Nurcholish Madjid, Abdurrahman Wahid, Ahmad Wahib, dan Djohan Effendy. ${ }^{6}$

Selepas menuntut ilmu secara akademis, Buya Syafii kemudian pernah menjabat sebagai Ketua Umum Pengurus Pusat Muhammadiyah (1998-2005). Dan kini beliau aktif dalam komunitas MAARIF Institute. Dan tentunya aktivitas yang tak pernah ditinggalkan adalah dunia kepenulisan, di samping menjadi pembicara dalam sejumlah seminar. Sebagian besar tulisannya adalah masalah-masalah Islam, dan dipublikasikan di sejumlah media cetak. Selain itu, ia juga menuangkan pikirannya dalam bentuk buku. Atas karya-karyanya, pada tahun 2008 Buya Syafii mendapatkan penghargaan Ramon Magsaysay dari pemerintah Filipina.

\section{Karya-Karyanya}

Diantara karya-karya hingga kini yang terdokumentasikan adalah sebagai berikut:

${ }^{4}$ Dalam peta intelektual muslim Fazlur Rahman dikenal sebagai tokoh reformis, radikal dan kontroversial, hal ini dapat dilihat dari karya-karya keislamannya; Prophecy in Islam: Philosophy and Ortodoxy (1958), Islamic Methodology in History (1965), Islam (1968), The Philosophy of Mulla Sadra (1975), Islam and Modernity: Transformation and Intellectual Tradition (1982), Major Themes of the Quran (1980). Dan karya-karya tersebut menempatkannya sebagai seorang tokoh neo-modernis Islam yang brilian.

5 Ahmad Syafii Maarif, Titik-Titik Kisar., hlm. 186-207.

6 Keempat tokoh tersebut dalam pemetaannya Greg Barton dianggap sebagai tokoh-tokoh yang memiliki suatu pemikiran dan gerakan yang berkarakteristik "liberal" di Indonesia. Terkait dengan term liberal, Charles Kurzman, di dalam bukunya Liberal Islam, A Sourcebook, menyebut enam gagasan yang dapat dipakai sebagai tolok ukur sebuah pemikiran Islam dapat disebut "Liberal" yaitu: (1). melawan teokrasi, yaitu ide-ide yang hendak mendirikan negara Islam; (2). mendukung gagasan demokrasi; (3). membela hak-hak perempuan; (4) membela hak-hak non-Muslim; (5) membela kebebasan berpikir; (6) membela gagasan kemajuan. Lihat, Charles Kurzman, Liberal Islam a Sourcebook:0. 
1. Mengapa Vietnam Jatub Selurubnya ke Tangan Komunis (Yogyakarta: Yayasan FKISIKIP, 1975)

2. Dinamika Islam (Jakarta: Shalahuddin Press, 1984)

3. Islam, Mengapa Tidak? (Jakarta: Shalahuddin Press, 1984)

4. Percik-percik Pemikiran Iqbal (Jakarta: Shalahuddin Press, 1984)

5. Al-Qur'an, Realitas Sosial dan Limbo Sejarah (Sebuah Refeleksi) (Bandung: Pustaka, 1985)

6. Studi tentang Percaturan dalam Konstituante; Islam dan Masalah Kenegaraan (Jakarta: LP3ES, 1985)

7. Peta Bumi Intelektualisme Islam di Indonesia (Bandung: Mizan, 1993)

8. Membumikan Islam (Yogyakarta: Pustaka Pelajar, 1995)

9. Mencari Autentisitas dalam Kegalauan (Jakarta: PSAP, 2004)

10. Menggugah Nurani Bangsa (Jakarta: MAARIF Institute, 2005)

11. Islam Kekuatan Doktrin dan Keagamaan Umat (Yogyakarta: Pustaka Pelajar, 1997)

12. Titik-titik. Kisar di Perjalananku; Autobiografi Abmad Syafii Maarif (Bandung: Mizan, 2009)

13. Islam dalam Bingkai Keindonesiaan dan Kemanusiaan (Bandung: Mizan dan MAARIF Institute, 2009)

\section{Kerangka Berpikir Ahmad Syafii Maarif: \\ Elaborasi Model Neo-Modernisme Islam Vs Pendekatan Kritis}

Seperti yang telah dikemukakan di atas, bahwa pemikiran Buya Syafii dipengaruhi oleh model-model pendekatan Neo-Modernisme Islam nya Fazlur Rahman. Dan seperti yang dijelaskan oleh Rahman sendiri bahwa gerakan pembaharuannya bertumpu pada pertama, perumusan pandangan dunia al-Quran. Kedua, menciptakan suatu analisis yang sistematis terhadap ajaran-ajaran moral al-Quran dan pada gilirannya akan tercipta etika al-Quran. Ketiga, merumuskan sistem dan formula hukum yang selaras dengan kebutuhan kontemporer berdasarkan etika tersebut. ${ }^{8}$ Arah gerakan Rahman ini mengambil bentuknya pada hipotesanya tentang arus kebangkitan Islam yang menyebar di dunia yang muncul sebagai reaksi yang kuat terhadap kelemahan ulama tradisional dan kegagalan negara Islam dalam menanggulangi pengaruh Barat. ${ }^{9}$ Singkatnya, model berpikir neo-modernisme Islam ala Rahman, seperti yang secara kritis diilustrasikan juga oleh Farid Essack dalam bukunya Qur'an, Liberation \& Pluralism, kalau dibentuk bagan akan seperti di bawah ini: ${ }^{10}$

\footnotetext{
7 Menurut Fazlur Rahman, Neo-Modernisne tidak lain merupakan modernisme Islam plus metodologi yang mantap untuk memahami al-Quran dan Sunnah Nabi dalam perpektif sosio-historis. Lihat, Ahmad Syafii Maarif, Peta Bumi Intelektualisme Islam di Indonesia (Bandung: Mizan, 1995), hlm. 138. Atau lebih detailnya baca, Fazlur Rahman, "Islam: Challenges and Opportunities" dalam Alford T. Welch \& Pierre Cachia (eds), Islam: Past Influence and Present Challenge (Edinburgh: Edinburgh University Press, 1979), hlm. 323-327.

8 Ihsan Ali Fauzi, "Menuju Sistematisasi Etika Al-Qur'an”, Al-Hikmah, No. 9, April-Juni, 1993, hlm. 41-42.

9 Wan Mohd. Nor Wan Daud, “Fazlur Rahman: Kesan Seorang Murid dan Teman”, Ulumul Qur'an, No. 8, Vol. II, (1991/1411 H), hlm. 109.

${ }^{10}$ Diagram ini dapat dilihat pada Farid Essack, Qur'an, Liberation \& Pluralism (England: Oneworld Oxford, 1997), hlm. 66-67.
} 


\section{Bagan I}

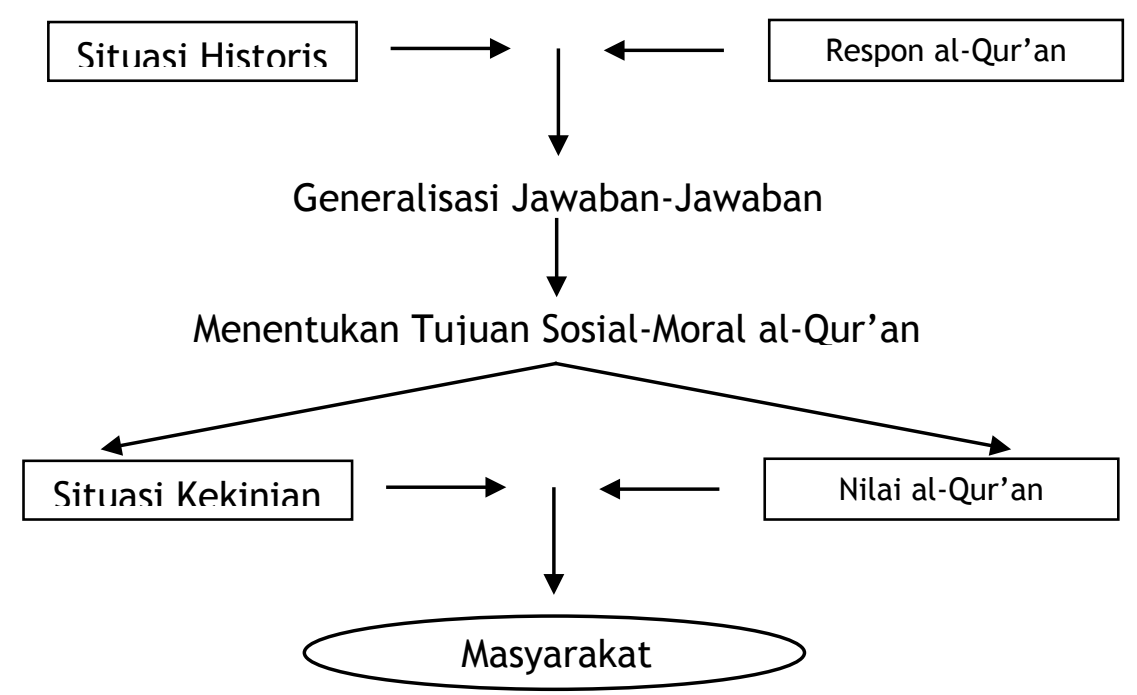

Dalam rumusan model di atas, pemikiran Islam Buya Syafii mengenai dasar-dasar Islam apakah itu konsepsinya tentang al-Quran dan Sunnah Nabi lahir dari bentuk pemahaman yang diperolehnya dari sang guru neo-modernisme Islam Fazlur Rahman.

Sementara pada sisi yang lain, selain pengaruh Rahman, Buya Syafii juga terpengaruh dengan pemikiran-pemikiran seperti Toynbee, Iqbal dan Hatta yang menurut hemat saya memberikan fondasi bagi lahirnya pemikiran kritisnya. Pendekatan kritis yang dimaksud, seperti yang diulas juga oleh Haryatmoko, ${ }^{11}$ nampak pada empat pernyataannya, yaitu pertama, agama tidak selalu berdaya mengawal perilaku penyimpangan kekuasaan yang dilakukan penguasa Muslim. Maka perlu sikap kritis untuk jujur terhadap masa lampau. ${ }^{12}$ Kedua, sejarah kepahitan harus dikatakan dan dibongkar meski harus menelanjangi diri karena sejarah merupakan pedoman bertindak dalam batas ruang dan waktu. Ketiga, ada kecenderungan manusia untuk menyembunyikan kepentingan-kepentingan di balik ayat-ayat suci. ${ }^{13}$ Dan keempat, tinggalkan sikap bangga dalam kesemuan, pakai ukuran akurat untuk berkaca diri secara kritis, jangan menyembunyikan kelemahan diri dan bersiaplah menertawakan diri sendiri. ${ }^{14}$

Menurut Haryatmoko, pendekatan kritis ini, selain mampu membongkar mitosmitos masa lampau dan legitimasi kekuasaan, juga merupakan kritik ideologi atau kritik terhadap keyakinan-keyakinan yang bisa berubah menjadi ilusi. Pengambilan jarak kritis ini memungkinkan membuka cakrawala baru sejarah dan terobosan di dalam melihat masa depan karena tidak terpasung oleh penafsiran yang mandek dan apologetis.

${ }^{11}$ Haryatmoko, "Islam Terbuka, Bersahabat, dan Dinamis", Jurnal MAARIF vol. 4, No. 1-Juli 2009. hlm. 34-35.

${ }^{12}$ Ahmad Syafii Maarif, Islam dalam Bingkai., hlm. 47.

${ }^{13}$ Ibid., hlm. 49.

${ }^{14}$ Ibid., hlm. 269. 
Kemampuan diri sendiri adalah bentuk kebebasan dan keterbukaan untuk berubah.

Cara berpikir Buya Syafii dengan mengelaborasi model neo-modernis Islam dan pendekatan kritis menjadikannya sebagai seorang yang memiliki integritas keislaman yang unik dan independen. Pemahaman Islam yang kontekstual dan substantif tapi tetap kritis pada alur perubahan yang bergerak.

\section{Islam: Agama Damai, Terbuka dan Dinamis}

Sengaja tulisan ini dimulai dengan mengupas soal term Islam dalam pemahaman Buya Syafii. Dengan mengetahui pandangan beliau mengenai agama ini maka setidaknya kita bisa mengetahui grand naratif yang hendak dicitrakannya kepada publik. Dan inilah yang menjadi dasar spektrumnya terhadap semua persoalan yang dipotretnya. Singkatnya, pemahamannya tentang Islam mewarnai pemikirannya tentang tema lainnya.

Dengan mengutip apa yang dikemukakan oleh Frithjof Schoun, bagi Buya Syafii,Islam dipahami sebagai agama yang secara tegas menawarkan prinsip keseimbangan kepada manusia, ${ }^{15}$ karena tujuan yang hendak dicapai oleh Islam adalah tegaknya prinsip-prinsip persamaan, keadilan, persaudaraan dan toleransi. Pandangan ini didasarkan pada beberapa ayat dalam al-Quran;al-Hujurât, 49:10, 13 dan 15; an-Nisâ', 4:58; an-Nahl, 16:90; al-Maidah, 5:8; al-Zumar, 39:18; al-Baqarah, 2:256.

Nilai-nilai di atas, menurut Buya Syafii, telah menghilang dari kehidupan umat, hingga Islam dilihat orang tampil dalam periode-periode tertentu dalam sejarah dengan wajah bopeng, jauh dari anggun. Di antara sebab utama mengapa situasi ini memudar adalah karena dasar etik yang dipedomani dalam kehidupan bukanlah sepenuhnya etik al-Quran, tapi lebih banyak etik golongan, suku, bangsa dan kelompok kepentingan. ${ }^{16}$ Dan bila hal ini yang terjadi, maka peradaban sebuah masyarakat akan mengalami kemunduran bahkan akhirnya digulung waktu ketika para pemimpinnya secara sadar membunuh nalar kreativitasnya dalam menanggapi pelbagai tantangan yang menghadangnya. ${ }^{17}$

Prinsip-prinsip Islam yang terbuka dan dinamis yang didasarkan pada etik al-Quran nampak sekali pada perjalanan sejarah Islam di Indonesia. Seperti yang dicatat oleh C. Snouck Hurgronje bahwa proses penyebaran Islam ke Nusantara berjalan secara damai. ${ }^{18}$ Islam sebagai pendatang baru telah menggeser peran dua agama besar sebelumnya (Budha dan Hindu). Gelombang besar Islamisasi terjadi pada masa Portugis, sebagian besar bangsawan masuk Islam sebagai upaya mereka melawan Kristenisasi jaman Portugis. Sedangkan Kristenisasi yang didukung oleh pemerintah kolonial, misalnya Gubernur Jendral Jan Pieter Zoon Koen (1587-1629) tidak berpengaruh besar terhadap perpindahan agama, meski menggunakan politik

${ }^{15}$ Menurut Frithjof Schoun, Islam adalah jalan keseimbangan dan jalan cahaya yang ditegakkan di atas landasan ikuibilirium yang kokoh. Kutipan ini disebut dalam, Ahmad Syafii Maarif, AlQur'an, Realitas Sosial Dan Limbo Sejarah (Sebuab Refleksi) (Bandung: Pustaka, 1985), hlm. 10.

${ }^{16}$ Ahmad Syafii Maarif, Membumikan Islam (Yogyakarta: Pustaka Pelajar, 1995), hlm. 34.

${ }^{17}$ Lihat pengantar Fajar Riza Ul Haq, "Sang Anak Panah: Sebuah Pengantar, Jurnal MAARIF vol. 4, No. 1-Juli 2009. hlm. 6.

${ }^{18}$ Snouck Hurgronje, Islam di Hindia Belanda, terj. S. Gunawan, Jakarta: Bhratara Karya Aksara, 1983), hlm. 9. 
beras. Terhadap cara Koen ini, Buya Syafii menyatakan, "Dalam perkembangan sejarah kemudian, cara-cara Koen ini tidak pernah efektif, karena pada umumnya iman yang dibeli dengan benda adalah sebuah iman yang berkualitas rendah." ${ }^{19}$ Singkatnya adalah ketidaktepatan membaca sejarah dan nilai etika al-Quran itulah yang menjadikan wajah Islam menjadi brutal, anarkis dan beku.

\section{Islam dalam Konteks Kemanusiaan dan Keindonesiaan}

Dalam bukunya Islam dalam Bingkai Keindonesiaan dan Kemanusiaan (2009), Buya Syafii mengemukakan empat hal yang menjadi kegalauannya, pertama, ia tidak rela bila bangsa ini tercabik-cabik oleh politik agama, kepentingan picik, lokal, dan primordialisme. Kedua, adanya kesenjangan antara ajaran dan praktek kehidupan, yaitu tiadanya korelasi antara praktek agama dan perbaikan moral. Di satu sisi, orang rajin beribadah, di sisi yang lain, korupsi semakin menggurita dan kekerasan menghancurkan bangsa ini. Ketiga, munculnya penyakit yang sifatnya kultural dan mental. Dan keempat, fenomena kemiskinan, dan kebodohan menimpa sebagian besar umat Muslim Indonesia. ${ }^{20}$

Terhadap empat hal yang menjadi keresahan tersebut, maka kata kunci yang menjadi penting dikemukakan adalah soal keterhubungan antara Islam, kemanusiaan, dan keindonesiaan. Penerimaan akan korelasi-intim ketiganya akan membuka jalan menuju ke arah Islam yang harus dikembangkan di Indonesia. ${ }^{21}$ Pengembangan model-ideal atas ketiga hal itu akan memberikan solusi tepat pada masalah-masalah yang menimpa bangsa dan negara ini.

Untuk merumuskan pola hubungan yang ideal tersebut, Buya Syafii menyodorkan asumsi-asumsi proposisional bahwa pertama, Islam Indonesia harus dilandaskan pada model Islam yang damai, karena demikianlah awalnya Islam masuk dan menjadi bagian penting bagi kehidupan masyarakat Indonesia. Cara damai ini seharusnya mampu memberi corak Islam yang terbuka, meneduhkan dan memberi kenyamanan kepada kelompok-kelompok agama-agama lain.

Kedua, sejarah menunjukkan bahwa para founding father bangsa ini, yang sebagian besar adalah muslim, baik yang berjuang dalam ranah partai atau gerakan nasionalis, secara de facto menerima sistem politik demokrasi, meski demokrasi masih banyak kelemahannya.

Ketiga, demokrasi tidak bisa dilepaskan dari penerimaan pluralitas dan adanya toleransi. Dalam konteks ini, masalah pencarian dasar negara menjadi polemik yang berkepanjangan antara Pancasila atau Islam. Dan Muhammadiyah dan NU telah menerima Pancasila sebagai dasar negara Indonesia, serta meninggalkan Piagam Jakarta dan menolak Khilafah Islamiyah.

Keempat, masa depan agama terletak di dalam upaya ijtihad. Maka peran pendidikan menjadi penting, bukan hanya dalam tujuan pragmatisnya, yaitu menekankan perolehan pengetahuan dan mempersiapkan untuk mendapatkan kesempatan kerja demi

\footnotetext{
${ }^{19}$ Ahmad Syafii Maarif, Islam dalam Bingkai Keindonesiaan dan Kemanusiaan (Bandung: Mizan dan MAARIF Institute, 2009), hlm. 116.

${ }^{20}$ Ahmad Syafii Maarif, Islam dalam Bingkeai., hlm. 22-82.

${ }^{21}$ Ibid., hlm. 15.
} 
meningkatkan kesejahteraan. Islam ingin memerangi kebodohan dan kemiskinan sebagian besar umatnya. Tekanan lain adalah pendidikan diarahkan untuk membantu mengembangkan kemampuan penalaran agar sanggup mempertanggungjawabkan pernyataan, keyakinan dan tindakannya.

\section{Simpulan}

Pemikiran keislaman Ahmad Syafii Maarif menempati ruang tersendiri dalam kancah pemikiran Islam Indonesia. Dengan berusaha memperkenalkan wajah Islam yang ramah, damai, toleran, kritis dan dinamis yang diderivasi dari pemahaman yang utuh terhadap pesan moral dan nilai-nilai universal al-Quran dan Sunnah Nabi. Syafii Maarif bukanlah seorang intelektual di menara gading karena ia telah menjadi bagian penting dari dinamika Muhammadiyah. Menurutnya, berkiprah dalam ormas Islam semacam Muhammadiyah menuntut kesabaran tingkat tinggi. Dalam konteks ini, ungkapan "Satu Kata, Satu Perbuatan” mencerminkan sebuah konsistensi intelektual dirinya yang dipengaruhi filosofi Iqbalian; filosofi yang menanamkan semangat kenabian di mana kesadaran langit (idealisme-Qurani) harus berjumbuh dengan faktafakta kesejarahan bumi (realitas).

Walaupun dikatakan sebagai pemikir agak terlambat (the late comer) munculnya dalam pentas tokoh Islam Indonesia, namun keberadaannya kini menjadi penting ketika tokoh-tokoh Islam yang dimiliki bangsa semakin 'menghilang' karena concern dan fokus perjuangannya telah bergeser pada wilayah yang pragmatis-politis. Dengan konsistensi yang dimiliki, maka layaklah intelektual dari ranah Minangkabau ini menjadi Guru Bangsa yang senantiasa kritis dan peka terhadap persoalan umat. Ikhtiar membangun Islam dalam bingkai keindonesiaan dan kemanusiaan dalam satu tarikan napas merupakan kerja dakwah dan kebudayaan yang diharapkannya berdaya jangkau jauh.

\section{Daftar Pustaka}

Barton, Greg, Gagasan Pemikiran Islam Liberal di Indonesia, Jakarta: Paramadina, 1999.

Daud, Wan Mohd. Nor Wan, "Fazlur Rahman: Kesan Seorang Murid dan Teman”, Ulumul Qur'an, No. 8, Vol. II, (1991/1411 H).

Dobbin, Christine, Islamic Revivalism in a Changing Peasant Economy: Central Sumatera, 1784-1847, London \& Malmo: Curzon Press, 1983.

Essack, Farid, Qur'an, Liberation \& Pluralism, England: Oneworld Oxford, 1997.

Fauzi, Ihsan Ali, "Menuju Sistematisasi Etika Al-Qur'an”, Al-Hikmah, No. 9, AprilJuni, 1993.

Haq, Fajar Riza Ul, "Sang Anak Panah: Sebuah Pengantar, Jurnal $M A A R I F$ vol. 4, No. 1-Juli 2009.

Haryatmoko, "Islam Terbuka, Bersahabat, dan Dinamis", Jurnal $M A A R I F$ vol. 4, No. 1-Juli 2009.

Hurgronje, Snouck, Islam di Hindia Belanda, terj. S. Gunawan, Jakarta: Bhratara Karya Aksara, 1983.

Kurzman, Charles, Liberal Islam a Sourcebook 
Maarif, Ahmad Syafii, Al-Qur'an, Realitas Sosial Dan Limbo Sejarah (Sebuah Refleksi), Bandung: Pustaka, 1985. , Islam dalam Bingkai Keindonesiaan dan Kemanusiaan, Bandung: Mizan dan MAARIF Institute, 2009. Membumikan Islam, Yogyakarta: Pustaka Pelajar, 1995. , Peta Bumi Intelektualisme Islam di Indonesia, Bandung: Mizan, 1995.

-----------, Titik-Titik Kisar di Perjalananku Autobiografi Abmad Syafii Maarif, Bandung: Mizan, 2009.

Rahman, Fazlur, "Islam: Challenges and Opportunities" dalam Alford T. Welch \& Pierre Cachia (eds), Islam: Past Influence and Present Challenge, Edinburgh: Edinburgh University Press, 1979. 